This work is licensed under a Creative Commons Attribution 4.0 International License.

Ovaj rad dostupan je za upotrebu pod međunarodnom licencom Creative Commons Attribution 4.0.

https://doi.org/10.31820/f.30.2.3

Vesna Cigan

\title{
TERMINOLOGICAL COLLOCATIONS AND TERM VARIATION IN MECHANICAL ENGINEERING DISCOURSE
}

mr. sc. Vesna Cigan, Fakultet strojarstva i brodogradnje, vesna.cigan@fsb.hr, Zagreb

izvorni znanstveni članak

UDK 81'373.7

81'276.6:62

rukopis primljen: 30. 8. 2018.; prihvaćen za tisak: 6. 12. 2018.

Terminological collocations ${ }^{1}$ are one of the most typical and very frequent units of representation of concepts in many disciplines. Although traditionally considered to be unwelcome in terminology, synonymy is amply present in specialized languages. Consequently, the same phenomenon is reflected in terminological collocations.

This paper aims to investigate synonymous collocations extracted from mechanical engineering texts in terms of the most frequent and relevant types of denominative variation in the selected English collocations as well as of their equivalents in German and Croatian. The analysis of variations in terminological collocations gives insight into the (non)substitutability of collocation constituents as one of the major characteristics of collocations. Extracted collocations are analysed within a two-tier framework structured at a paradigmatic and a syntagmatic level, which allows for the identification of the three types of term variation: morphological, syntagmatic and semantic. Focusing on the collocations with the structure noun + noun and adjective + noun the results show that constituents of both syntactic

1 as defined by Bukovčan (2009: 165): lexicalised, two-word expressions with domainspecific content, characterized by conventionality and lexical validity, also used by Silvia Pavel (1993) and Laura Giacomini (2015) 
structures allow substitution. The denominative variants are prevalent in adjective + noun collocations in which synonymous lexical elements functioning as collocates do not entail a concept change (admissible load $\leftrightarrow$ allowable load). Lexeme substitutions are also annotated in noun + noun collocations expressing a slightly different dimension or facet of the concept (face gear vs. crown gear vs. crown wheel). The majority of German equivalents are nominal compounds that outnumber their morphological variants offering multiple equivalences.

Keywords: terminological collocations; term variation; variant types; substitutability

\section{Introduction}

Science, research and other specialist areas have recently undergone the development and diversification of specialist knowledge marked by an increased need for specialist communication at a global level. The complexity of technical advancements and innovative breakthroughs has called for creating new denotations to represent new concepts and referents. Terminology development has played a significant part in facilitating communication between experts around the world encountering a tremendous increase in expertise in numerous disciplines. The exchange of knowledge among experts engaged in domain specific communication does not occur through completely fixed packages of information but rather in an on-going process of development. Development, adjustment and change are necessarily connected to the functioning of language in real life communication (Engberg, 2003: 19).

In order to enable a speaker to turn reality into language, concepts need to exist in one's mind as well as a relation to a referent (object of reality). To that end terminology is used for naming concepts and retrieving information (Cabré, 1995: 6). The traditional theory of terminology according to Wüster aims "to achieve univocity in professional communication, especially at the international level" (Cabré, 2000: 41). The ideal of univocity has recently been challenged by cognitive science, linguistics and communication sciences particularly in the light of subsequent contributions to Wüster's theory and the relevant research results applying the interdisciplinary approach. Although a strong proponent of unambiguous accurate professional communication Wüster realized the divergence of his ideal terminological system from specialized language reality and accepted that synonymous word combinations with understandable elementary re- 
lationships and specializations impose less burden on the memory, nevertheless are unavoidable when they express a different perception of the same concept (Wüster, 1970: 96).

Terminological units are used to represent knowledge and label the blocks of knowledge corresponding to the concepts of special domains (e.g. STEM fields). One of the most productive ways of term formation in domain specific language is compounding i.e. the combination of words into multi-word naming units. The creative potential of language becomes evident in a communication process and plays an essential role in the naming processes leading to the variation of lexical forms and phenomena like polysemy (semantic openness of one form), synonymy (alternative denominations for the same concept) or hyponymy (semantic subordination).

\section{Terminological collocations and term variation}

\subsection{Discussion on collocations}

Despite a very extensive research, there is still no consensus among scholars on the definition of collocations. For the purpose of this paper, a brief overview of a few most commonly accepted definitions and categorisations of collocation will be given. In his lexicographic approach ${ }^{2}$ Hausmann (1984, 1985 and 1995) defines collocation primarily as a binary unit or a typical combination of two words ("Zweierkombinationen von Wörtern") characterised by habitualness, frequent co-occurrence of its constituent parts as well as their specific semantic hierarchical relationship. One of the collocation constituents, called base, keeps its meaning ("semantisch autonom", Hausmann, 2004) and acts as the dominant constituent, whereas the other constituent, the collocate, is dependent and deemed to be dominated by the base ("semantisch abhängig"). Following the corpus linguistic approach Sinclair sees collocations as "the occurrence of two or more words within a short space of each other within a text" (Sinclair 1991: 170). Smadja (1993) identifies four characteristics of collocations that have implications for different perspectives, namely that collocations are arbitrary, domain independent ${ }^{3}$, recurrent and cohesive lexical clusters.

\footnotetext{
2 all emphasized parts of the text by V.C.

3 A different view can be put forward regarding the domain dependency, since terminological collocations are domain specific i.e. domain dependent as they are generated and used only in specific fields.
} 
Principally, definitions of collocations have been built up on four basic factors:

1. frequency and recurrence of word combinations,

2. collocability (constrained lexical selection),

3. semantic transparency or opacity,

4. specific relations between constituents.

These factors give rise to an extensive elaboration of specific features of collocations classified as morphosyntactic, semantic and conceptual properties. Collocations occur in both general language and specific domain language. Comparing basic properties of collocations in general language the characteristics of terminological collocations at several linguistic levels are adopted as proposed by Caro Cedillo (2004: 87). The phenomenon of collocating can be understood as a synthesis that takes place at the conceptual, lexical, syntactic and pragmatic level, and can only be explained by including all of them.

In the Croatian linguistic tradition and research, the phenomenon of collocation has predominantly been investigated in general language. Although both collocations in general language and LSP collocations have recently received more attention from researchers, a lack of systematic theoretical and applied linguistic research findings regarding this phenomenon is reflected in a multitude of terms used to determine a word cluster in linguistics referred to as collocation. ${ }^{4}$ Among Croatian linguists an extensive research on general language collocations was conducted by Blagus Bartolec (2012, 2014) who offers a term collocational phrase (kolokacijska sveza) and a rather complete definition ${ }^{5}$ focusing on both the semantic relations of constituent lexical units and syntagmatic aspects (emphasizing the structure of two autosemantic words). Marija Turk (2018) examines the relationship between collocations and idioms pointing to their complex and multi-faceted features which make the task to distinguish them difficult. Focusing on the semantic aspects B. Petrović (2008: 589) observes that compared to free syntagms collocations are firmer and more restrictive, thereby exhibit-

4 sveze riječi, višerječne jedinice, višečlani nazivi, višeleksičke jedinice, višeleksičke sveze, višerječne natuknice, višerječne sveze, skupine riječi, skupovi riječi, sintagmemi

5 "Collocational phrase is a special lexical combination at the syntagmatic level based on semantic connectedness of independent lexical units which influences and specifies their meanings." (Blagus Bartolec, 2014: 80), translated by VC. 
ing limited or no substitutability of either constituent element. Directing attention to semantic features B. Tafra (2005: 120) distinguishes lexicalisation and syntagmatisation as two methods to generate word combinations. The connectedness of words into a collocational phrase should be observed as a result of the syntagmatisation, firmer lexical and syntagmatic relation of words, which can be applied to explain semantic relation within a collocational phrase. Significant research was also conducted by Stojić and Murica (2011) (Stojić, 2012) based on contrasting of collocations in German and Croatian.

\subsection{Demarcation line: collocations vs. free word combinations and phrasemes}

Although a number of criteria have been proposed to distinguish collocations from free combinations on the one side from idioms on the other side on the scale between these two extremes, the borders cannot be specified clearly. Collocations differ from free lexical combinations in that they are "semantically arbitrary restrictions which do not follow logically from the propositional meaning of a word" (Baker, 1992: 14). Phrases characterized as 'free' usually mean "syntactic constructions that are formed according to syntactic and semantic rules" (Irsula Peña 1994: 15). According to M. Benson (1985: 5) two features that distinguish a collocation from a free phrase are its frequency and rather low possibility that semantic concept contained in a collocation can be expressed by other word connections. Collocations cannot be equated with the free lexical combinations because they exhibit a certain degree of fixedness.

The borderlines between the idiomatic and the non-idiomatic phrases are not always stable, and clear, but permeable so that the properties overlap. According to Burger (2007: 101) "the term collocations denotes fixed word connections which show no or only very weak idiomatic transformations of meaning". Whereas Fleischer holds the opinion that collocations cannot be considered phrasemes, since they are not stable and transparent (1997: 250), Busse defines collocations as "alle regelmäßig auftretenden syntagmatischen Kombinationen von Lexemen; feste - und damit phraseologische - Kollokationen sind die Teilmenge aus ihnen" (2002: 4).

As discussed above, criteria to distinguish collocations from other multi-word expressions involve syntactic, semantic and pragmatic descriptions. Those that are relevant to the present study can be briefly summarized as 
occurrence, collocability, semantic relations, metaphoricity and terminologisation. We also adopt the criterion of semantic transformation as proposed by Blagus Bartolec (2012: 52). Thus, every collocation is a multi-word expression, but not every multi-word expression is a collocation.

\subsection{Terminological collocations}

When functioning as a language sign, collocations are used to designate concepts specific to a particular field or discipline, thereby belonging to a structured system. Within that system they establish relationships with other units on the same level, as well as to the units on the other levels with which they build the discourse (Cabré, 1989: 82).

In order to qualify for categorization as a terminological unit, a collocation needs to exhibit the typical characteristics of a term (Lérat, 1989: 54):

- its expression is a symbol

- it results from a convention

- its content is its most important trait

- the concept it represents is explicitly defined

- the description of a concept leads to the field of knowledge in which it occurs.

Within the Communicative Theory of Terminology (Cabré, 2003: 183) a terminological unit is understood as a three-component unit: a unit of knowledge, a unit of language and a unit of communication, and it needs to be described from these three perspectives. Cabré further notes the specificity of terminological units that "resides in the fact that they fulfil restricted conditions in each of their cognitive, grammatical and pragmatic constituent components" (2003: 183). When these observations are applied to collocations, similarity can be perceived on a number of dimensions, which should be proven by the analysis of the respective corpus.

Studied from the semantic point of view, distinctive facets of a collocation can be found in the specific semantic relations between the base and the collocate. While the base in principle has the same meaning as outside the collocation (Burger, 2007: 102), the collocate participates with one of its semes and influences the semantic or conceptual relation to the base or specializes its meaning. The main distinguishing feature of terminological collocations is more specialised nomination (bearing $\leftrightarrow$ roller bearing) within a specific domain. The definition proposed by Bukovčan (2009: 165) 
covers all relevant aspects in that terminological collocations are lexicalised two-word expressions with domain-specific content, characterized by conventionality and lexical validity. Terminological collocations satisfy the lexicographic criteria for distinguishing terms from general language phrases since they are units of thought, refer to a single concept and designate it in a particular subject field, are used in a specialized area of knowledge and are part of a hierarchical classification (Turk, 2000: 478).

\subsection{Term variation}

Although argued to be undesirable in languages for specific purposes, synonyms are more common in a variety of communicative settings in which terminology is used by experts than initially expected. Terms as a means of expression and professional communication with the purpose of knowledge transfer are subject to variation due to different underlying factors discussed later in the text. Many scholars investigated term variation to explore and identify its causes and motivation, but also to detect regularities and universalities (Cabré, 2003, 2008; Daille, 2005; Freixa, 2002).

Based on Cabré's classification (2008), Aguado de Cea and MontielPonsoda define three types of term variants (2012: 201):

1. Term variants that are semantically coincident but formally different, also referred to as synonyms or terminological units that totally correspond to the same concept (shaft strength $\leftrightarrow$ strength of the shaft) ${ }^{6}$;

2. Term variants that are semantically and formally different, but still refer to the same ontological concept. In this case, each variant may highlight one facet of the same concept or serve a certain purpose (coil spring $\leftrightarrow$ spiral spring, plain bearing $\leftrightarrow$ slide bearing $)^{7}$, and,

3. Term variants that are semantically and formally different and point to two related, but also different, ontological concepts, which means that they are also conceptually different (roller bearing $\leftrightarrow$ rolling bearing) ${ }^{8}$.

Term variant has been defined by Daille et al. (1996) as "an utterance which is semantically and conceptually related to an original term". This definition is further explicated by defining its three important points. 'An

6 retrieved from the English sub-corpus

7 ibid.

8 ibid. 
utterance' is a variant of a term in an attested form encountered in a text (Daille, 2005: 182). 'Original term' is considered to be a variant defined from an authorised term both listed in a thesaurus or in a terminological resource and accepted by a community of experts. This term variant can be related to the original term in three ways a) by a synonym of an authorised term, b) by reflecting semantic distance and c) by reflecting a conceptual link. Daille presents four different typologies of variations pointing out that they depend on the application and computer techniques involved (e.g. information retrieval, text indexing, terminology watch and controlled terminology for computer-assisted translation systems).

In keeping with the proposed typologies, we have identified and adopted for this research three main types of term variation as recognized during the analysis:

1. morphological variants:

a) inflectional (various forms of a same word according to number, gender, person, tense) tooth contact $\rightarrow$ teeth contact

b) derivational (words of different parts of speech) adjectival form or a noun tension $\rightarrow$ tensile

2. syntagmatic variants (grammatical reformulations): the two syntactic structures, compound or syntagmatic, under which a term can appear shaft diameter $\rightarrow$ diameter of the shaft

3. semantic (different lexical choice) tempered gear and hardened gear.

As the original terms under consideration are collocations, each type of variants was further analysed in terms of both relations between collocation constituents and variant semantic properties.

\section{Methodology}

This paper aims to investigate the denominative variants ${ }^{9}$ of terminological collocations extracted from mechanical engineering texts in English, German and Croatian, as the synonymy becomes more perceptible when equivalents are compared across languages.

The study is based on three sub-corpora generated in accordance with a set of common criteria: language, genre and size. As the corpora of differ-

\footnotetext{
9 As defined by Daille, denominative variants are lexicalised forms offering alternative forms to name or represent the same concept $(2017: 5,30)$.
} 
ent languages but similar genre allow language comparison (Eckart and Quasthoff, 2010), the compiled sub-corpora are of a similar size and composition and with matching structural features. Each sub-corpus contains the original texts in a specialised narrow domain of mechanical engineering, in particular authentic and highly regarded educational textbooks in three different languages and the Croatian National Termbank STRUNA (Table 1). From the content point of view the issue of representation has also been taken into account as compiled sub-corpora concentrate on machine elements as a specific subfield in mechanical engineering, representing a "cross-section" of discourse (Teubert, 2005: 4). The three sub-corpora can be deemed comparable also in terms of time span as they were published within a six-year period (2005-2011).

Table 1. Textbooks constituting the three sub-corpora

\begin{tabular}{|c|c|c|}
\hline Language & Textbooks & $\begin{array}{l}\text { Number } \\
\text { of words } \\
\text { (tokens) }\end{array}$ \\
\hline \multirow[t]{2}{*}{ English } & $\begin{array}{l}\text { Baumeister H., Baldo A. et.at.: Machine Elements, } \\
\text { In: Mark's Standard Handbook for Mechanical Engineers, } \\
\text { 2006, Mc Graw-Hill Professional, New York }\end{array}$ & \multirow[t]{2}{*}{247,252} \\
\hline & $\begin{array}{l}\text { Boris M. Klebanov, David M. Barlam, Frederic E. Nystrom: } \\
\text { Machine elements: Life and design, 2008, CRC Press }\end{array}$ & \\
\hline German & $\begin{array}{l}\text { Decker, Karl Heinz: Machinenelemente. Funktion, } \\
\text { Gestaltung und Berechnung (18th edition), 2011, Carl } \\
\text { Hanser Verlag, München }\end{array}$ & 300,097 \\
\hline \multirow{4}{*}{ Croatian } & $\begin{array}{l}\text { Decker, Karl Heinz: Elementi strojeva, Tehnička knjiga, } \\
\text { Zagreb, 1987, translated by: Alfred Heim, Edmund Kron, } \\
\text { Eugen Oberšmit, 3rd edition, Golden marketing- } \\
\text { Tehnička knjiga, } 2006\end{array}$ & \multirow[t]{3}{*}{254,039} \\
\hline & Jelaska, Damir: Elementi strojeva, Sveučilište u Splitu, 2005 & \\
\hline & $\begin{array}{l}\text { Domazet, Željko and Krstulović-Opara, Lovre: Skripta iz } \\
\text { osnova strojarstva, Sveučilište u Splitu, } 2006\end{array}$ & \\
\hline & $\begin{array}{l}\text { Croatian National Termbank STRUNA } \\
\text { Book 14: Hrvatsko nazivlje strojnih elemenata }\end{array}$ & 56,760 \\
\hline
\end{tabular}

The study presented in this paper was performed in several steps. Applying statistical linguistic methods and the freeware concordance program AntConc (Anthony, Windows, version 3.5.0, Dev) including tools for frequen- 
cy counts, collocational analysis and cluster analysis, first frequency-sorted lists were created from each monolingual sub-corpus. In each list the twenty most frequent lexical words were identified and used to generate collocation candidates. In the next step, the Collocates Tool settings were set to search for collocates in a horizon of five words to the left and five to the right. The list of frequencies of co-occurring words also showed the statistical measures MI (Mutual information) or t-score. The Clusters Tool was used to retrieve word patterning i.e. to extract a two-word sequence composed of a key word (the base) and its collocate. The lists of the first 100 results (collocations) for each language were used to identify and manually select synonymous collocation pairs or triples (Eng - Ger - Cro) based on informed intuition (Deignan, 2005: 93). In line with Firth's famous claim "You shall know a word by the company it keeps" (1957: 11), the Concordance Tool was used to check how the collocations containing the key words are used in sub-corpus texts (the key-word-in-context method) but also to verify whether the key words are part of a multi-word collocation.

As Hoffmann points out (1985: 105), components of terminological collocation exhibit structural features common to languages for specific purposes. One feature particularly evident in a collocation at the morphological and syntactical level is a noun playing a vital role. In line with Hoffmann's claim Caro Cedillo also observes that the component serving as the base in terminological collocation is typically a noun or a nominal term, but very often both components are terms (Caro Cedillo, 2004: 79). Drawing on these findings and the lists of collocation candidates, in the present study special attention was directed toward collocations with the structure noun + noun and adjective + noun as well as their equivalents in the two contrasted languages (English to German and/or Croatian).

A total of 76 synonymous terminological collocations have been extracted from the English sub-corpus to serve as the starting sample for the contrastive analysis. To ensure the reliability of the selected sample, the obtained term variants were validated in the authoritative monolingual and bilingual dictionaries:

- Mc-Graw-Hill: Dictionary of Engineering

- The free dictionary / thesaurus https://www.thefreedictionary.com/,

- Leo.org online dictionary https://www.leo.org/german-english/),

- Luzer and Spinčić: Englesko-hrvatski enciklopedijski brodostrojarski rječnik. 
In the next step the appropriate equivalents in German and Croatian were identified and assigned to the English collocations. Once the pairs or triples are identified, the synonymous collocations were examined at the syntagmatic and paradigmatic level. Further analysis was performed applying the basic principles of lexical semantics (Cruse, 2004; Lyons 1991, 1996) and cognitive linguistics (Croft and Cruse, 2004; Fernandez-Silva et al, 2011), aiming to show the relations between the collocation constituents (dependency, directionality), the relations between the variants in each language (formation of meaning) and the differences across contrasted languages. The interlingual constrastive analysis of the domain specific languages reveals that collocability can be manifested at varying degrees and in different ways assuming the preservation of functional equivalence (Bukovčan, 2009: 170).

\section{Results and discussion}

Based on the most frequent lexical words in English and their counterparts in the two contrasted languages (Table 2) the retrieved two-word sequences allowed us to filter the noun-noun collocations and adjectivenoun collocations.

Table 2. The most frequent lexical words retrieved from the sub-corpora

\begin{tabular}{|c|l|l|l|}
\hline & \multicolumn{1}{|c|}{ Eng } & \multicolumn{2}{c|}{ De } \\
\hline 1. & load & Belastung & opterećenje \\
\hline 2. & shaft & Welle & vratilo \\
\hline 3. & stress & Beanspruchung & naprezanje \\
\hline 4. & gear & Zahnrad & zupčanik \\
\hline 5. & strength & Festigkeit & čvrstoća \\
\hline 6. & force & Kraft & sila \\
\hline 7. & bearing & Lager & ležaj \\
\hline 8. & bolt & Schraube & vijak \\
\hline 9. & contact & Kontakt & kontakt \\
\hline 10. & tooth & Zahn & zub \\
\hline 11. & surface & Fläche & površina \\
\hline 12. & shear & Scherung & smik \\
\hline 13. & hub & Nabe & glavina \\
\hline 14. & deformation & Deformation & deformacija \\
\hline 15. & connection & Verbindung & spoj \\
\hline
\end{tabular}




\begin{tabular}{|l|l|l|l|}
\hline & \multicolumn{1}{|c|}{ Eng } & \multicolumn{1}{c|}{ De } & \multicolumn{1}{c|}{ Hr } \\
\hline 16. & pressure & Druck & tlak \\
\hline 17. & torque & Drehmoment & moment \\
\hline 18. & friction & Reibung & trenje \\
\hline 19. & calculation & Berechnung & proračun \\
\hline 20. & spring & Feder & opruga \\
\hline
\end{tabular}

The list of collocations was futher filtered and a somewhat greater number of occurrences of the synonymous collocations in the English subsample was identified for the adjective-noun collocation pattern (Figure 1).

Figure 1. Patterns of synonymous collocations as per occurences

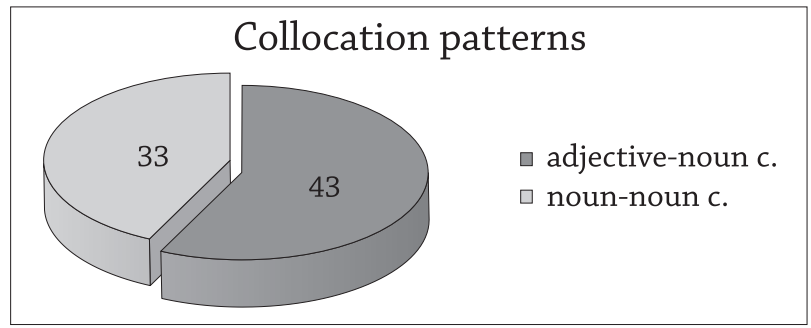

The majority of nominal constituents of the extracted collocations, both noun-noun and adjective-noun collocations, have term status thus forming terminological collocations. Different types of a term variation in the retrieved collocations in English (Table 3) are analysed and then compared to their counterparts in German and Croatian.

Table 3. Variations for the English sub-corpus

\begin{tabular}{cll} 
Collocation pattern & \multicolumn{1}{c}{ Variants (POS) } & Variant pattern \\
\hline \multirow{3}{*}{ Noun + noun } & Type $_{1}=\mathrm{N}_{1}$ of $\mathrm{N}_{2} \longrightarrow$ syntactic \\
$\mathrm{Type}_{2}=\mathrm{N}_{2} \mathrm{~N}_{3} \longrightarrow$ semantic \\
$\mathrm{N}_{2} \mathrm{~N}_{1}$ & Type $_{3}=\mathrm{AN} \longrightarrow$ derivational \\
& Type $_{4}=$ ing- $\mathrm{AN}$ & inflectional
\end{tabular}

Adjective + noun

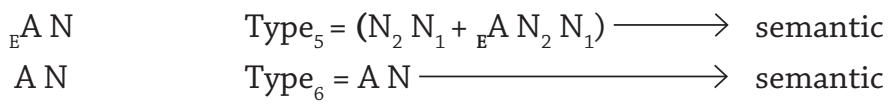




\subsection{Noun + noun collocations}

Although somewhat underrepresented in the subsample with 33 occurrences, the noun-noun collocation pattern involves four variation types exhibiting several patterns: syntactic variation of permutation, synonymic lexical substitution and morphological variation.

\subsubsection{Type variants $\left(\mathrm{N}_{1}\right.$ of $\left.\mathrm{N}_{2}\right)$}

The prevailing pattern of variants for noun-noun collocations is noun + preposition of + noun which permutes the linear order of the constituents and forms an inverted form of $\mathrm{N}_{2} \mathrm{~N}_{1}$ (e.g. shaft deformations and deformations of the shaft) (Table 4). Permutation variation takes place around the preposition of which has a relational function. The lexemes of the original terms are in reverse order without any further insertion and retain the same dependency relation: $\mathrm{N}_{1}$ is modified by $\mathrm{N}_{2}$. An additional search in the authoritative dictionaries has confirmed the finding that this type of variant is the most frequent one.

Table 4. Syntactic variations for noun + noun collocations

\begin{tabular}{llll} 
Lang. & \multicolumn{1}{c}{$\mathrm{N}_{2} \mathbf{N}_{1}$ collocation } & $\Rightarrow$ & \multicolumn{1}{c}{ Type $_{1}$ variant } \\
\hline Eng & shaft deformations & $\Rightarrow$ & deformations of the shaft \\
Ger & Wellendeformation & $\Rightarrow$ & $\varnothing$ \\
Cro & deformacija vratila & $\Rightarrow$ & diameter of the shaft \\
\hline Eng & shaft diameter & $\Rightarrow$ & Durchmesser der Welle \\
Ger & Wellendurchmesser & $\Rightarrow$ & $\varnothing$ \\
Cro & promjer vratila & $\Rightarrow$ & strength of the shaft \\
\hline Eng & shaft strength & $\Rightarrow$ & Festigkeit der Welle \\
Ger & Wellenfestigkeit & $\Rightarrow$ & $\varnothing$ \\
Cro & čvrstoća vratila & $\Rightarrow$ & force of the bolt \\
\hline Eng & bolt force & $\Rightarrow$ & Kraft der Schraube \\
Ger & Schraubenkraft & $\Rightarrow$ & $\varnothing$ \\
Cro & sila vijka &
\end{tabular}

The German equivalents of $\mathrm{N}_{2} \mathrm{~N}_{1}$ collocations are noun compounds (e.g. Wellendeformation), also called ordinary compounds (Amiot and Dal, 2005), the components of which are lexical and semantic equivalents of the English constituent lexemes (shaft $=$ Welle; deformation $=$ Deformation) and follow the linear order. The variant for the German noun compound is a 
noun followed by a modifying genitive noun, the pattern consistent with the Croatian equivalents that are found to have no variants. The order of the German variant and Croatian equivalent consitutents is reversed thereby retaining the same semantically determined relationship. Within this hierarchical relation of modification, so common in collocations, the determinant (collocate) specifies different aspects and distinctive features of the concept (base).

\subsubsection{Type ${ }_{2}$ variants $\left(\mathrm{N}_{2} \mathrm{~N}_{3}\right)$}

The linguistic operation generating the Type ${ }_{2}$ variations is the synonymic lexical substitution. According to Tafra (1996: 78) the substitution is precisely the method for verifying the synonymy of the two words. The term variantions involve the synonymic substitution on the base (head) (Tables $5-7$ ) allowing for one of the components in a syntactic position to remain identical.

Table 5. Substitution of constituent elements in base position (English)

\begin{tabular}{llll} 
Lang. & \multicolumn{1}{c}{$\mathrm{N}_{2} \mathrm{~N}_{1}$ collocation } & & \multicolumn{1}{c}{ Type variant $\left(\mathrm{N}_{2} \mathrm{~N}_{3}\right)$} \\
\hline Eng & shaft misalignment & $\Rightarrow$ & misalignment of the shaft \\
& & $\Rightarrow$ & shaft displacement \\
Eng & bearing surface & $\Rightarrow$ & bearing area \\
Eng & air pocket & $\Rightarrow$ & air trap \\
Eng & shear elasticity & $\Rightarrow$ & shear modulus \\
& & $\Rightarrow$ & modulus of rigidity
\end{tabular}

There is considerable variability in the English variants and their counterparts in German and Croatian. In addition to the syntactic variant (shaft misalignment $\leftrightarrow$ misalignment of the shaft) the lexeme misalignment is substituted by its competing lexeme displacement without changing either the collocation pattern or the meaning at the collocation level (Table 7).

In the group of Type ${ }_{2}$ variants $\left(\mathrm{N}_{2} \mathrm{~N}_{3}\right)$ a variation subtype can be identified. A double variation is noted to appear as both type $\mathrm{N}_{1}$ of $\mathrm{N}_{2}$ and type $\left(\mathrm{N}_{2} \mathrm{~N}_{3}\right.$ ) (Table 6). 
Table 6. Substitution of constituent elements in base position - double variants (English)

\begin{tabular}{llll} 
Lang. & $\mathrm{N}_{2} \mathrm{~N}_{1}$ collocation & & Variant subtype $\left(\mathrm{N}_{1}\right.$ of $\mathrm{N}_{2}$ and $\left.\mathrm{N}_{2} \mathrm{~N}_{3}\right)$ \\
\hline \multirow{2}{*}{ Eng } & shaft misalignment & $\Rightarrow$ & misalignment of the shaft \\
& & $\Rightarrow$ & shaft displacement
\end{tabular}

Table 7. Substitution of constituent elements in base position (contrastive)

\begin{tabular}{llll} 
Lang. & \multicolumn{1}{c}{$\mathrm{N}_{2} \mathbf{N}_{1}$ collocation } & & \multicolumn{1}{c}{ Type $_{2}$ variant } \\
\hline Eng & shaft misalignment & $\Rightarrow$ & $\begin{array}{l}\text { misalignment of the shaft } \\
\text { shaft displacement }\end{array}$ \\
Ger $\quad \begin{array}{l}\text { Wellenversatz } \\
\text { Wellenfehlausrichtung } \\
\text { cro } \quad \text { otklon vratila }\end{array}$ & $\Rightarrow$ & $\begin{array}{l}\text { Fehlausrichtung der Welle } \\
\text { necentriranost vratila } \\
\text { osni pomak vratila }\end{array}$
\end{tabular}

As per German counterparts two variations were found: the semantic variant of the noun compound comprising different lexemes and its syntactic variant. The competing lexemes serving as a base in the English (misalignment $\leftrightarrow$ displacement) and their counterparts in the German and Croatian collocations (Versatz $\leftrightarrow$ Fehlausrichtung and otklon $\leftrightarrow$ necentriranost) when verified and compared outside the collocation were found to be semantically equivalent. They focus on the local dimension in terms of spatial property of a thing (shaft) and highlight the deflection from its initial position or mark its motion. The interlinguistic symmetry is also noticed in the suffixes mis-, dis-, ver- and fehl- all highlighting fault, failure, error or wrong position, though not found in all Croatian equivalents. The concept of deflection or deviation is included in the constituent otklon. The prefix $n e$ - in the synonymous equivalent denotes an insufficiently performed action or an action that has not been carried out to the extent required or usually assumed.

\subsubsection{Type ${ }_{3}$ variants (A N)}

Although the terms generated by the derivational processes change the syntactic category or word class and often entail a change in meaning, the sub-corpora of this study indicated otherwise. In the English subsample synonymy in the Type ${ }_{3}$ variants occurs in the collocate (tension $\leftrightarrow$ tenstile) position without any semantic change (Table 8 ). 
Table 8. Type ${ }_{3}$ variants (adjective-noun collocations)

\begin{tabular}{llll} 
Lang. & \multicolumn{1}{c}{$\mathrm{N}_{2} \mathrm{~N}_{1}$ collocation } & & \multicolumn{1}{c}{ Type $_{3}$ variant $(\mathrm{A} \mathrm{N})$} \\
\hline Eng & tension stress & $\Rightarrow$ & tensile stress \\
Ger & Zugspannung & $\Rightarrow$ & Zugbeanspruchung \\
Cro & vlačno naprezanje & $\Rightarrow$ & rastezno naprezanje \\
Eng & compression stress & $\Rightarrow$ & compressive stress \\
Ger & Druckspannung & $\Rightarrow$ & Druckbeanspruchung \\
Cro & tlačno naprezanje & $\Rightarrow$ & pritisno naprezanje
\end{tabular}

Comparing German and Croatian equivalents in terms of their components semantic variations are noted in the base (Spannung $\leftrightarrow$ Beanspruchung) and collocate position (vlačno $\leftrightarrow$ rastezno, tlačno $\leftrightarrow$ pritisno). The competing lexemes in the base position Spannung and Beanspruchung are found in textbooks to be substituable for each other imposing no semantic difference in the relevant context (1).

(1) Erst damit kommt man zu einer Vorstellung über den Beanspruchungszustand (Spannungszustand) des betrachteten Bauteils und kann etwas über die Verteilung der inneren Kräfte aussagen. (Böge, 2011: 282)

Furthermore, these lexems are terms that highlight two conceptually related concepts linked through a hyponymic relation (2).

(2) Die Festigkeitslehre ist ein Teil der Mechanik. Sie behandelt die Beanspruchungen, das sind die Spannungen und Formänderungen, die äußere Kräfte (Belastungen) in festen elastischen Körpern (Bauteilen) auslösen. (Böge, 2011: 282)

As per Croatian counterparts prenominal adjectives modifing the base vlačno $\leftrightarrow$ rastezno and tlačno $\leftrightarrow$ pritisno are terminologically relevant as they belong to a specific domain language used to denote a certain phenomenon. They are fully interchangeable and manifest a high degree of semantic overlap because, in Cruse's words (1986: 267), their senses are identical in respect of their 'central' semantic traits. 


\subsubsection{Type $_{4}$ variations (ing-Adj. N)}

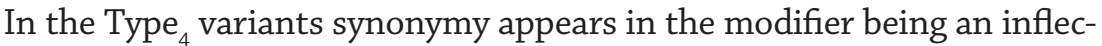
tional variant in the form of the present participle (Table 9). Since inflectional categories generally do not alter the basic meaning of a lexeme, the constituents of the term variants shear $\leftrightarrow$ shearing and drive $\leftrightarrow$ driving exhibit a high degree of semantic overlap emphasizing the progressive aspect i.e. the active role of the entity in question as well as an ongoing action.

Table 9. Type ${ }_{4}$ variants (ing-Adj. N)

\begin{tabular}{llll} 
Lang. & \multicolumn{1}{c}{$\mathrm{N}_{2} \mathrm{~N}_{1}$ collocation } & & \multicolumn{1}{c}{ Type $_{4}$ variant } \\
\hline Eng & shear force & $\Rightarrow$ & shearing force \\
Ger & Scherkraft & $\Rightarrow$ & Schubkraft \\
Cro & smična sila & $\Rightarrow$ & smik \\
& & $\Rightarrow$ & posmična sila \\
& & $\Rightarrow$ & sila smicanja \\
\hline Eng & drive shaft & $\Rightarrow$ & driving shaft \\
Ger & Antriebswelle & $\Rightarrow$ & Antriebsachse \\
& & $\Rightarrow$ & Treibewelle \\
& & $\Rightarrow$ & Triebwelle \\
Cro & pogonsko vratilo & $\Rightarrow$ & ulazno vratilo
\end{tabular}

Drive and shaft are means by which a certain operation is carried out and they share the same ability of transmitting motion or power from one machine part to the other. Similarly, both prenominal modifiers (drive (n.) and driving (ing-adj.)) express and refer to the same act causing machine parts to function. Consequently, these variants also allow for a full contextual interchangeability as they both convey the same information about the phenomen i.e. the machine part having no conceptual consequences.

The variants of German equivalents, predominantly noun compounds, involve a different lexical choice denoting the same concept. Both lexemes Scherung and Schub share a high degree of semantic similarity and the same denotative meaning signaling a spatial aspect and a physical action of moving or transferring something from one place to another. Another important element that contributes to semantic overlapping is the special type of force involved and the direction in which this force acts. 
In addition to the Croatian single-word term smik, which per definition includes distinctive features of the concept ${ }^{10}$, the variant posmična ${ }^{11}$ sila is a one-to-one equivalent of shear force and a complete synonym of smična sila standing in a symmetric relation as defined by Cruse (1996: 113). In comparison to the variant sila smicanja, a pattern $A+N$ as of posmična sila is preferred over the noun + genitive noun pattern (Hudeček and Mihaljević, 2009: 62).

Although inflectional classes, as exemplified above, principally do not cause a meaning change, ing-Adj. $\mathrm{N}$ variant rolling bearing is found to be a broader term.

Table 10. Roller bearing vs. rolling bearing

\begin{tabular}{llll} 
Lang. & \multicolumn{1}{c}{$\mathrm{N}_{2} \mathrm{~N}_{1}$ collocation } & & \multicolumn{1}{c}{ Type $_{4}$ variant } \\
\hline Eng & roller bearing & $\Rightarrow$ & rolling bearing \\
Ger & Wälzlager & $\Rightarrow$ & Rollenlager \\
& & $\Rightarrow$ & Walzenlager \\
& & $\Rightarrow$ & Rolllager \\
Cro & valjkasti ležaj & $\Rightarrow$ & valjni ležaj
\end{tabular}

Despite the fact that roller bearing and rolling bearing are not completely synonymous ${ }^{12}$ they are used interchangeably in the context. A more detailed analysis will reveal contextual clues to the relation between these two terms.

Different applications in engineering require specific types of bearings that operate on different principles e.g. nature of the contact (friction) and load type. These two major criteria give rise to the classification of numerous specific types of bearings. These terms being a part of a structured linguistic system establish relationships to other terms within the same specific domain. The nominal modifier (collocate) roller specifies one partic-

\footnotetext{
10 smik is defined as a shift or movement in the direction of force action

11 a nominal premodifier highlighting the direction of force and movement

12 The term complete synonymy was used by Lyons (1981: 148) to define lexemes that have the same descriptive, expressive and social meaning in a certain range of contexts denoting the same referent. In this study the term complete synonymy refers to collocations and term variants denoting the same referent in the subject field and exhibiting a high degree of semantic overlap.
} 
ular category of the object (base), more specifically it indicates a distinctive shape and adds perceptual features of a bearing type as evident from the definition (3).

(3) roller bearing $=a$ shaft bearing characterized by parallel or tapered steel rollers confined between outer and inner rings (McGraw-Hill, 2003: 467)

The linguistic operation applied to produce a variant rolling bearing is lexical reduction. The term rolling bearing is derived from rolling-element bearing by the removal of the lexical constituent element. Whereas the modifier roller highlights the form, the modifier rolling points to a functional property selected to differentiate the referent, also assigning a narrower, more specialized sense. The relation that holds between these two terms is a relation of hyponymy i.e. type-of relation ("X is a kind of Y") as they share the same notion of the rotating and revolving motion, and one of them possesses a further feature. Roller bearing having an additional, more specific feature (differentia specifica) is a sub-type of the superordinate rolling-element bearing (genus proximum) (Figure 2).

Figure 2. Classification of bearings (Childs, 2014: 140)

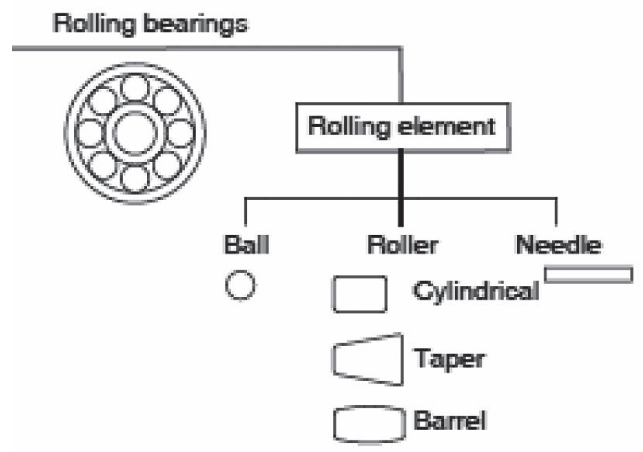

As per German and Croatian equivalents the same relation of hyponymy was identified as with the English hyponymous pair. The determining constituent Wälz- of the noun compound Wälzlager is derived from the verb wälzen (roll, revolve) pointing to the inherent function of the bearing (collocational base) i.e. enabling the desired rotational or linear motion (4) (Cro. valjni). The determinants in the variants Walzenlager, Rollenlager, Rollager 
and valjkasti signify the form of the rolling elements enclosed between two races (5). In terms of taxonomic hierarchy German and Croatian equivalents exhibit congruent correlation with English terms.

(4) Wälzlager ist Lager, bei dem die Reibung durch das Rollen eingebauter Walzen o. Ä. erfolgt. (Duden)

(5) Rollenlager ist Lager, bei dem mithilfe von Rollen oder Walzen Schwankungen in der Lage ausgeglichen werden können und die Reibung sich verringert. (Duden)

\subsection{Adjective + noun collocations}

In the due course of the analysis two types of adjective-noun collocations were identified: those containing eponymous adjectives (Table 11) and those with general adjectives (Table 12). Unlike variants for the nounnoun collocations, variants of the adjective-noun collocations have predominantely the same structure $(\mathrm{A} \mathrm{N})$ in which an adjective serving as collocate precedes and modifies a base (noun) and is subject to substitution.

\subsubsection{Type ${ }_{5}$ variants $\left(\mathrm{N}_{2} \mathrm{~N}_{1}\right.$ and $\left.\mathrm{A} \mathrm{N}_{2} \mathrm{~N}_{1}\right)$}

Typically, onyms are very common in the terminology as the concepts are designated based on the relation to the inventors or discoverers.

Table 11. Substitution of onymous element in collocate position

\begin{tabular}{llll} 
Lang. & \multicolumn{1}{c}{${ }_{\mathrm{E}}$ A N collocation } & \multicolumn{1}{c}{ Type $_{5}$ variant $\left({ }_{\mathrm{E}} \mathrm{AN}\right)$} \\
\hline Eng & Hertzian stress & $\Rightarrow$ & contact stress \\
& & $\Rightarrow$ & Hertzian contact stress \\
Ger & Hertzsche Pressung & $\Rightarrow$ Hertzsche Spannung \\
& & & \\
Cro $\quad$ Hertzovo naprezanje & $\Rightarrow$ Hertzov kontaktni pritisak \\
& & $\Rightarrow$ kontaktni pritisak \\
& & $\Rightarrow$ kontaktno naprezanje \\
& $\Rightarrow$ dodirno naprezanje
\end{tabular}

The term Hertzian stress comprises a personal name (onym) stressing the discoverer of the phenomenon. Heinrich Rudolf Hertz was the first to 
solve the contact problem of two elastic bodies with curved surfaces. One of the retrieved variants focuses on the phenomenon dimension, whereas the other includes both the onym and the phenomenon designation. In the German equivalent two competing equivalents for the constituent stress are found: lexemes Pressung and Spannung pointing to the different perspectives taken when describing the phenomenon. Pressung (Eng. pressure) is a force acting perpendicular to a surface trying to compress the surface on which it acts thereby causing stress (Ger. Spannung) - a reaction produced by the molecules of the body. The same variation pattern is noted in the Croatian equivalents. The lexemic substitution occurs in both the determinant i.e. collocate and the base. In addition to the adjective derived from onym Hertzov(o) the Croatian variants are formed with the adjectival collocates kontaktno and dodirno both being completely synonymous. Scrutinized in a given context, the variants allow for a full interchangeability entailing the same communicative effect consequently complying with the requirements suggested by Geeraerts that the substitution must work in both directions (2010: 84).

Table 12. Type ${ }_{6}$ variants $(A N)$

\begin{tabular}{llll} 
Lang. & \multicolumn{1}{c}{ A N collocation } & & \multicolumn{1}{c}{ Type $_{6}$ variant } \\
\hline Eng & working load & $\Rightarrow$ & operating load \\
Ger & Betriebsbelastung & $\Rightarrow$ & betriebliche Belastung \\
& & $\Rightarrow$ & Betriebslast \\
Cro $\quad$ radno opterećenje & $\Rightarrow$ & $\varnothing$ \\
\hline Eng & fluctuating load & $\Rightarrow$ & variable load \\
& & $\Rightarrow$ & varying load \\
& & $\Rightarrow$ & oscillating load \\
& & $\Rightarrow$ & alternating load \\
Ger & ungleichförmige Belastung & $\Rightarrow$ & swinging load \\
Cro & oscilirajuće opterećenje & $\Rightarrow$ & njihajuće opterećenje \\
& & $\Rightarrow$ & promjenjivo opterećenje \\
\hline Eng & admissible stress / load & $\Rightarrow$ & allowable stress / load \\
& & $\Rightarrow$ permissible stress / load \\
& & $\Rightarrow$ & maximal stress / load \\
Ger & zulässige Spannung & $\Rightarrow$ & zulässige Beanspruchung \\
Cro & dopušteno naprezanje & $\Rightarrow$ & $\varnothing$
\end{tabular}


The majority of variations of the terms shown in Table 12 are generated by substitution in the collocate position without any semantic change as they convey the same information about the determined constituent load: working $\leftrightarrow$ operating; Betriebs- $\leftrightarrow$ betriebliche; oscilirajuće $\leftrightarrow$ njihajuće. As evident from other examples, the substitution in the base position is found only in the German variant (synonym pairs Spannung $\leftrightarrow$ Beanspruchung, Belastung $\leftrightarrow$ Last), whereas some of Croatian terms have no variants. In an interlingual comparison adjective-noun collocations in German and Croatian proved to be equivalent terms as they share all of their essential elements.

A more in-depth analysis reveals the compositionality of the collocation constituents and the meanings contained in synonymous lexemes. In line with Cruse's observation that a synonym is often employed as an explanation, or clarification, of the meaning of another word (Cruse, 1996: 109), operate and work appear in dictionary definitions of either words interchangeably (6).

(6) operate, verb (Oxford Learner's Dictionaries)

1 [intransitive] + adv./prep. to work in a particular way $\rightarrow$ synonym function

2 [transitive] operate something to use or control a machine or to make it work

work, verb (Oxford Learner's Dictionaries)

5 [intransitive] + adv./prep. to function, to operate

6 [transitive] work something to manage or operate something to gain benefit from it

7 [transitive] work something to make a machine, device, etc. operate

Besides a semantic interrelationship of determination between the collocates working $\leftrightarrow$ operating and their base load, an additional sense is noted. Operating and working refer to conditions under which a machine is performing or able to perform its regular function during which a certain amount of load occurs or is exerted. In this sense operating and working entail the concept of the maximum load that a machine is designed to bear. The base load influences the selection of the lexical meaning of the collocates in that it is complemented by the meaning maximum that provides further explicit specification. The comparison of collocations from other 
domains e.g. operating budget, operating system, working draft, working parts reveals different meanings of collocates contributed to the meaning of the collocation. Among scholars who observed this phenomenon (e.g. Firth's 'meaning by collocation'; 'mutal expectancy') Ivir argues that the specific meaning of each of the collocates does not only result from the collocational relation but also from their non-specific prototypical meaning existing as a meaning potential realized within selectional restrictions imposed by the collocational relation (Ivir, 1992-1993: 185).

The same meaning of "having or being the greatest quantity of the highest degree that has been or can be attained" (maximum by its definition) ${ }^{13}$ is comprised in the collocations admissible load, allowable load and permissible load exemplifying the principle of interrelationship described in the previous case. The net of relationships be it conceptual or semantic exists between the lexeme maximum and collocates admissible, allowable and permissible as indicated by the definition: as large, fast, etc. as is possible, or the most that is possible or allowed (Oxford Learner's Dictionaries) and their substitutability with the lexeme maximum i.e. maximal as in maximal load/stress.

\section{Conclusion}

The aim of this paper was to examine domain-specific collocations and their denominative variations retrieved from mechanical engineering textbooks in English as well as their counterparts in German and Croatian targeted at the identification of the most frequent and relevant types of variants. As the analysis of the extracted noun-noun and adjective-noun collocations reveals, the denominative variants are prevalent in adjectivenoun collocations, whereas the variants of noun-noun collocations exhibit more variability in that five patterns fall into three types of denominative variations: morphological, syntagmatic and semantic.

As confirmed, term variants are generated by a synonymic substitution of either of the collocation constituents whereby one of the constituents remains the same. The substitution of a collocation constituent was more frequent in the modifier i.e. collocate position. The modifier component of the adjective-noun collocation can be replaced with more than one synononymous lexeme generating several variants (e.g. allowable) without a change in meaning. The highest degree of synonymy occurs in

13 The free dictionary 
the modifier as it adds a narrower specification to the base which is the representation of the main complex technical or scientific concept. Furthermore, the noun components of collocations are typically terms in the relevant domain to which their synonymous lexemes belong, as well as collocation constituting adjectives.

The findings of the interlingual comparison show a high degree of terminological and functional equivalences and no collocational gaps between the subsamples. A greater number of denominative variants was found in the German than in the Croatian subsample. The prevalent counterpart type in German is a noun compound with $80 \%$ of the total number of German equivalents and almost $60 \%$ of all variants with synonymous lexemes in both collocate and base positions.

It is noteworthy that the denominative variants in the languages under consideration exhibit a high degree of semantic overlapping, the fact of crucial importance from the expert communication point of view within the specific technical or scientific discourse. In the globalized world science and technology have been progressively developing and have become more specialised. In view of the expansion of knowledge and the increasing complexity of specialist communication exchanged in the technologized and multilingual society, the terminology plays an important disambiguating role in representing the knowledge and new concepts that need denomination.

Therefore, comparative studies, particularly those of different languages based on smaller multilingual corpora allow for the identification of similarities and differences in domain-specific languages and make a considerable contribution to efficient professional communication among subject specialists with regard to terminological accuracy, precision and univocity.

\section{References}

Aguado de Cea, Guadalupe, Elena Montiel-Ponsoda (2012) "Term variants in ontologies", in: XXX Congreso Internacional de AESLA 2012, 19.04.2012 - 21.04.2012, Universidad de Lleida, 436-443, retrieved from http://oa.upm.es/19602/1/INVE_MEM_2012_137765.pdf

Amiot, Dany, Georgette Dal (2005) “Integrating Neoclassical Combining Forms into a Lexeme-based Morphology", in: On-line Proceedings of the 5th Mediterranean Morphology Meeting (MMM5), eds. G. Booij, L. Ducceschi, B. Fradin, E. Guevara, A. Ralli, S. Scalise, Fréjus, 323-336. 
Baker, Mona (1992) In Other Words. A Coursebook on Translation. Routledge, London.

Benson, Morton (1985) "Lexical cominability", Research on Language \& Social Interaction, 18, 1, 3-15.

Blagus Bartolec, Goranka (2012) "Kolokacijske sveze prema drugih leksičkim svezama u hrvatskom jeziku", Fluminensia, 24, 2, 47-59.

Blagus Bartolec, Goranka (2014) Riječi i njihovi susjedi. Kolokacijske sveze u hrvatskom jeziku, Institut za hrvatski jezik i jezikoslovlje, Zagreb.

Bratanić, M., \& Ostroški Anić, A. (2012) "Pedagoški pristup korpusno utemeljenoj izradbi kolokacijskog rječnika strukovnoga nazivlja”, Filologija, $58,39-54$.

Bukovčan, Dragica (2009) "Istovrijednost terminoloških kolokacija - komparativni pristup", in Jezična politika i jezična stvarnost, Hrvatsko društvo za primijenjenu lingvistiku - HDPL, ed. Jagoda Granić, Zagreb, 164-173.

Burger, Harald (2007) "Semantic aspects of phrasemes" in: Phraseologie. Phraseology Ein internationales Handbuch der zeitgenössischen Forschung. An International Handbook of Contemporary Research, eds. Burger, Harald et al., Walter de Gruyter, Berlin, New York, 90-110.

Busse, Dietrich (2002) “Wortkombinationen”, in: D. Alan Cruse et. al. (eds.) Lexikologie. Ein internationales Handbuch zur Natur und Struktur von Wörtern und Wortschätzen. (Handbücher zur Sprach- und Kommunikationswissenschaft), de Gruyter, Berlin/New York, 408-145.

Cabré, Teresa M. (1995) “On diversity and terminology”, Terminology, 2, 1, 1-16.

Cabré, Teresa M. (1999) Terminology: theory, methods and applications, edited by Juan C. Sager and translated by Anne DeCesaris, John Benjamins, Amsterdam/Philadelphia.

Cabre, Teresa M. (2000) “Do we need an autonomous theory of terminology?", Terminology, 5, 1, 2-20.

Cabre Catellví, Teresa M. (2003) "Theories of terminology. Their description, prescription and explanation", Terminology, 9, 2, 163-199.

Cabre Catellví, Teresa M. (2008) "El principio de poliedricidad: la articulación de lo discursivo, lo cognitivo y lo lingüístico en Terminología (I)", Ibérica 16, 9-36. 
Caro Cedillo, Ana (2004) Fachsprachliche Kollokationen. Ein übersetzungsorientiertes Datenmodell Deutsch-Spanisch, Gunter Narr Verlag, Tübingen.

Crof, William, Alan D. Cruse (2004) Cognitive linguistics, Cambridge University Press, Cambridge.

Cruse, D. A. (1986) Lexical Semantics, Cambridge University Press, Cambridge.

Cruse, D. A. (2004) Meaning in Language: An Introduction to Semantics and Pragmatics, Oxford University Press, Oxford.

Daille, Béatrice; Benoît Habert, Christian Jacquemin, Jean Royauté (1996) "Empirical observation of term variations and principles for their description", Terminology, Vol. 3, 2, 197-257.

Daille, Béatrice (2005) "Variations and application-oriented terminology engineering”, Terminology, 11, 1, 181-197.

Deignan, Alice (2005) Metaphor and Corpus Linguistics, John Benjamins, Amsterdam.

Eckart, Thomas, Uwe Quasthoff (2010) "Statistical Corpus and Language Comparison using Comparable Corpora", in: Proceedings of the $3^{\text {rd }}$ Workshop on Building and Using Comparable Corpora, LREC 2010, Malta, 15-20.

Engberg, Jan (2003) "Dynamics of meaning - an under-exposed feature of LSP linguistics", in: LSP Translation in the New Millennium, ed. Peter Kastberg, Hermes, Aarhus.

Fernandez-Silva, Sabela, Judit Freixa, Teresa Cabré M. (2011) “A proposed method for analysing the dynamics of cognition through term variation", Terminology , 17, 1, 49-73.

Firth, John Rupert (1957) A Synopsis of Linguistic Theory, 1930-1955, Studies in Linguistic Analysis, Special Volume of the Philogical Society, Oxford, 1-32.

Fleischer, Wolfgang (1997) Phraseologie der deutschen Gegenwartssprache, Niemeyer (2. Aufl.), Tübingen.

Geeraerts, Dirk (2010) Theories of Lexical Semantics, Oxford University Press, Oxford - New York.

Giacomini, Laura (2015) "Context-dependent variation of LSP collocations: A corpus-based Analysis", Procedia - Social Behavioral Sciences, 198, 140-148. 
Hausmann, Franz Josef (1984) "Wortschatzlernen ist Kollokationslernen. Zum Lehren und Lernen französicher Wortverbindungen”, Praxis des neusprachlichen Unterrichts, 31, 4, 395-406.

Hausmann, Franz Josef (1985) "Kollokationen im deutschen Wörterbuch. Ein Beitrag zur Theorie des lexikographischen Beispiels, Lexikographie und Grammatik", in: Akten des Essener Kolloqiums zur Grammatik im Wörterbuch, eds Henning Bergenholtz, Joachim Mugdan, Tübingen, 118-129.

Hausmann, Franz Josef (1995) "Von der Unmöglichkeit der kontrastiven Lexikologie", in: Von der Allgegenwart der Lexikologie, eds. Kromann, H. P., Kjær, A. L., Max Niemeyer Verlag, Tübingen.

Hausmann, Franz Josef (2004) "Was sind eigentlich Kollokationen?", in: Wortverbindungen - mehr oder weniger fest. Jahrbuch des Instituts für Deutsche Sprache, ed. Katrin Steyer, Berlin - New York, 309-334.

Heid, Ulrich (1998) "A linguistic bootstrapping approach to the extraction of term candidates from German text", Terminology, Vol. 5, 1, 161-181.

Hoffmann, Lothar (1985) Kommunikationsmittel Fachsprache. Eine Einführung, G. Narr, Tübingen.

Hudeček, Lana, Milica Mihaljević (2009) Hrvatski terminološki priručnik, Institut za hrvatski jezik i jezikoslolje, Zagreb.

Irsula Peña, Jesús (1994) Substantiv-Verb-Kollokationen: Kontrastive Untersuchungen Deutsch-Spanisch, Peter Lang, Frankfurt am Main/Berlin/ Bern/New York/Paris/Wien.

Ivir, Vladimir (1992-1993) "Kolokacije i leksičko značenje”, Filologija, Knjiga 20-21, Zagreb, 181-189.

Lérat, Pierre (1989) "Les fondements théoriques de la terminologie", La Banque des mots, special Issue, 51-62, in: Cabré, Teresa M. (1999) Terminology: theory, methods and applications, edited by Juan C. Sager and translated by Anne DeCesaris, John Benjamins, Amsterdam Philadelphia.

Lyons, John (1981) Language and Linguistics: An Introduction, Cambridge University Press, New York.

Lyons, John (1991) Natural language and universal grammar: Essays in linguistic theory. Volume I. Cambridge University Press, New York.

Lyons, John (1996) Linguistic Semantics, Cambridge University Press, New York. 
Pavel, Silvia (1993) "Neology and phraseology as terminology-in-the-making", in Terminology: Applications in Interdiciplinary Communication, eds. Sonneveld, H. S.; Loening, K. L., Amsterdam, John Benjamins Pulishing Company, 21-34.

Petrović, Bernardina (2008) "Glagoli emocionalnih stanja u kolokacijskim strukturama i leksikografskom opisu”, 589-599, Riječki filološki dani, Filozofski fakultet, Rijeka.

Sinclair, John (1991) Corpus, Concordance, Collocation, Oxford University Press, Oxford.

Smadja, Frank (1993) "Retrieving collocations from text: Xtract”, Computational Linguistics, 19, 1, 143-177.

Stojić, Aneta (2012) Kolokacije. Prilog teoriji i praksi, Filozofski fakultet Sveučilišta u Rijeci, Rijeka.

Stojić, Aneta, Sanela Murica (2011) "Kolokacije - teorijska razmatranja i primjena u praksi na primjerima iz hrvatskoga i njemačkoga jezika”, Fluminensia, 22, 2, 111-125.

Tafra, Branka (1996) "Bliskoznačni odnosi u leksiku”, Filologija 26, Zagreb, 73-84.

Tafra, Branka (2005) Od riječi do rječnika. Školska knjiga, Zagreb.

Teubert, Wolfgang (1996) “Comparable or Parallel Corpora?”, International Journal of Lexicography, 9, 3, 238-264.

Teubert, Wolfgang (2005) "My version of corpus linguistics", International Journal of Corpus Linguistics, 10, 1, 1-13.

Turk, Marija (2000) "Višečlani izrazi s desemantiziranom sastavnicom kao nominacijske jedinice”, in Riječki filološki dani 3, Stolac, Diana (ed), Filozofski fakultet Sveučilišta u Rijeci, Rijeka, 477-486.

Turk, Marija (2018) "Od kolokacije do frazema", in Od dvojbe do razdvojbe. Zbornik u čast profesorici Branki Tafri, P. Košutar, M. Kovačić (eds), Ibis grafika Zagreb, Zagreb, 225-237.

Wüster, Eugen (1970) Internationale Sprachnormung in der Technik, besonders in der Elektrotechnik (Die nationale Sprachnormung und ihre Verallgemeinerung) third edition, Bouvier, Bonn. 


\section{Dictionaries and textbooks referred to in the article}

Baumeister Heard, Antonio Baldo et al. (2006) "Machine Elements", in: Mark's Standard Handbook for Mechanical Engineers, Mc Graw-Hill Professional, New York.

Böge, Alfred (2011) Handbuch Maschinenbau. Grundlagen und Anwendungen der Maschinenbau-Technik, 20th edition, Vieweg+Teubner / Springer, Wiesbaden.

Childs, Peter R. N. (2014) Mechanical Design Engineering Handbook, Elsevier, Amsterdam.

Decker, Karl Heinz (2006) Elementi strojeva, Tehnička knjiga, Zagreb, translated by: Alfred Heim, Edmund Kron, Eugen Oberšmit, 3rd edition, Golden marketing-Tehnička Knjiga, Zagreb.

Decker, Karl Heinz (2011) Machinenelemente. Funktion, Gestaltung und Berechnung (18th edition), Carl Hanser Verlag, München.

Domazet, Željko, Lovre Krstulović-Opara (2006) Skripta iz osnova strojarstva, Sveučilište u Splitu, Split.

Duden-Deutsches Universalwörterbuch, Dudenredaktion, www.duden.de Jelaska, Damir (2005) Elementi strojeva, Sveučilište u Splitu, Split.

Klebanov, Boris M.; Barlam, David M. and Nystrom, Frederic E. (2008) Machine elements: Life and design, CRC Press, Boca Raton, Florida

Leo.org online dictionary https://www.leo.org/german-english/)

Luzer, Josip, Aristide Spinčić, A. (2013) Englesko-hrvatski enciklopedijski brodostrojarski rječnik. Školska knjiga. Zagreb.

McGraw-Hill (2003) Dictionary of Engineering, McGraw-Hill Companies, New York.

Oxford Learner's Dictionaries (2018) https://www.oxfordlearnersdictionaries.com/definition/english/, Oxford University Press

STRUNA http://struna.ihjj.hr/

The free dictionary/thesaurus https://www.thefreedictionary.com/ 


\section{SAŽETAK \\ Vesna Cigan \\ TERMINOLOŠKE KOLOKACIJE I TERMINOLOŠKA SINONIMIJA U JEZIKU STROJARSTVA}

Terminološke su kolokacije tipične i vrlo česte leksičke jedinice reprezentacije pojmova u mnogim znanstvenim i tehničkim disciplinama. Iako se sinonimija smatra nepoželjnom u terminologiji, u jezicima struke učestalo se pojavljuje. Stoga ju kao jezičnu pojavnost pronalazimo i u terminološkim kolokacijama.

Cilj je ovoga rada istražiti sinonimne kolokacije u tekstovima iz područja strojarstva u pogledu čestotnosti i tipologije denominativnih varijanata u odabranim engleskim kolokacijama kao i njihovim istovrijednicama u njemačkome i hrvatskome jeziku. Analiza varijanata terminoloških kolokacija daje uvid u (ne)zamjenjivost sastavnih dijelova kolokacija kao jedne od njihovih glavnih značajki. Ekstrahirane kolokacije analizirane su primjenom dvostupanjskog okvira strukturiranog na paradigmatskoj i sintagmatskoj razini, što omogućuje identifikaciju triju tipova terminološke sinonimije: morfološke, sintagmatske i semantičke varijante. Rezultati analize dviju skupina kolokacija sa strukturom imenica + imenica i pridjev + imenica pokazuju da sastavni dijelovi obiju sintaktičkih struktura dopuštaju supstituciju. Terminološka sinonimija prevladava u kolokacijama sa strukturom pridjev + imenica u kojima sinonimne leksičke sastavnice u funkciji kolokatora ne utječu na promjenu sadržaja pojma (admissible load $\leftrightarrow$ allowable load). Leksička supstitucija također se pronalazi u kolokacijama sa strukturom imenica + imenica uz ponešto drukčiju dimenziju ili aspekt pojma (face gear vs. crown gear vs. crown wheel). Većina njemačkih istovrijednica su imeničke složenice koje čestotnošću nadmašuju svoje morfološke varijante i nude brojne istovrijednice.

Ključne riječi: terminološke kolokacije; terminološka sinonimija; tipovi varijanti; supstitucija 